\title{
First report of Pseudo-nitzschia brasiliana and P. micropora (Bacillariophycea) found in Cuyutlan Lagoon, Mexico
}

Primer reporte de Pseudo-nitzschia brasiliana y P. micropora

(Bacillariophycea) en la Laguna de Cuyutlán, México

\section{Sonia Quijano-Scheggia ${ }^{1}$, Aramis Olivos-Ortiz ${ }^{1}$, Juan Heberto Gaviño-Rodríguez ${ }^{1}$, Fátima Castro-Ochoa ${ }^{2}$, María Rivera-Vilarelle ${ }^{2}$, Marco Galicia-Pérez ${ }^{1}$ and Manuel Patiño-Barragan ${ }^{1}$}

${ }^{1}$ Centro de Universitario de Investigaciones Oceanológicas, Universidad de Colima, Carretera Manzanillo-Barra de Navidad km 20, Col. El Naranjo, C.P.28860, Manzanillo, Colima, México. quijano@ucol.mx

${ }^{2}$ Facultad de Ciencias Marinas, Universidad de Colima, Carretera Manzanillo-Barra de Navidad km 20, Col. El Naranjo, C.P. 28860, Manzanillo, Colima, México

\begin{abstract}
Resumen. - Las especies dominantes de las comunidades fitoplanctónicas presentes en un evento de proliferación algal son identificadas y descritas en la Laguna de Cuyutlán, México. El muestreo se llevó a cabo a principios de diciembre de 2009 en ocho estaciones. Se observan variaciones en salinidad y la temperatura de la laguna, posiblemente provocadas por el intercambio de marea. Los valores más altos de temperatura y salinidad fueron registrados en las estaciones internas. Debido a la evaporación la salinidad es más alta que en el océano adyacente y en contra parte valores similares a los del océano fueron detectados en las estaciones cercanas al Canal de Tepalcates. Los valores de oxígeno disuelto se relacionaron directamente con la profundidad y la hidrodinámica de la zona de muestreo. Cerca del canal de Tepalcates se produce un alto intercambio de agua océano-laguna que disminuye en las áreas más alejadas. Este intercambio permite una mayor resuspensión de material sedimentado (con alto material orgánico), por esto las altas concentraciones de nutrientes inorgánicos disueltos se presentaron en áreas menos profundas, influenciadas por la hidrodinámica y liberación desde los sedimentos y los tiempos de retención mayores en las estaciones internas (del orden de 2 días), mientras que las bajas concentraciones se midieron en las proximidades del Canal de Tepalcates. Las interacciones biofísicas determinaron la composición taxonómica de los principales grupos del fitoplancton en el área de estudio. Los grupos fitoplanctónicos están dominados por diatomeas principalmente del género Pseudo-nitzschia, seguido de nanoflagelados. Tres especies de Pseudo-nitzschia fueron identificadas: P. delicatissima, que es potencialmente tóxica, P. brasiliana y P. micropora, cuyo registro es el primero para la costa Pacífica Mexicana.
\end{abstract}

Palabras clave: Fitoplancton, diatomeas, laguna costera, parámetros fisicoquímicos

\begin{abstract}
The dominant communities of phytoplankton species present during a bloom event in Cuyutlan Lagoon, Mexico, were identified and subsequently described. Sampling was carried out in early December 2009 at eight stations. Variations in the lagoon's salinity and temperature were observed and probably corresponded to tidal exchanges. Maximum values of temperature and salinity were measured at internal stations. Due to evaporation, salinity is higher than in the ocean, and values similar to those of the ocean were determined at stations near the Tepalcates channel. Dissolved oxygen values were directly related to the depth and hydrodynamics of the sampled waters. Close to the Tepalcates channel there is a high exchange of lagoon-ocean water, and those further away have little exchange. This exchange allows for a greater sediment material resuspension (with high organic matter), due to this, this study found higher concentrations of inorganic dissolved nutrients occurring in shallower areas, influenced by the hydrodynamics of sediment release and the maj or retention times at internal stations (in order of 2 days), while lower concentrations were measured in proximity to the Tepalcates Channel. Bio-physical interactions determine the taxonomic composition of the main phytoplankton groups in the study area. These phytoplankton groups are dominated by diatoms primarily of the genus Pseudo-nitzschia, followed by nanoflagellates. Three Pseudo-nitzschia species were identified, P. delicatissima, which is potentially toxic, P. brasiliana and P. micropora, which are recorded for the first time on the Mexican Pacific coast.
\end{abstract}

Key words: Phytoplankton, diatoms, coastal lagoon, physicochemical parameters 


\section{INTRODUCTION}

Tide-dominated coastal lagoons are complex and dynamic ecosystems whose chemical, physical, and biological properties show wide spatial variations ranging from daily to seasonal. Recent increases in anthropogenic activities have affected the internal processes that define these ecosystems, due to ocean-continent interactions. Continental discharges (runoff from urban, industrial, and agricultural activities) typically contain high concentrations of nitrogen and phosphorous. The constant influx of these and other nutrients into coastal zones produces a regional enrichment where consequences include atypical microalgal blooms (some of which are toxic) and changes in composition of the phytoplankton communities (Kress et al. 2002, Colbert \& McManus 2003).

Most phytoplankton is unicellular or in relatively simply organized colonies of autotrophic organisms that are broadly dispersed in the ocean (Tomas 1997, Falkowski et al. 1998, 2004). Their abundance in oceanic, fresh, and brackish water bodies is determined by several abiotic factors, such as light, temperature and nutrients. Along the coast, phytoplankton are found where conditions that sustain their abundance and diversity prevail; however, extremely high abundances, in the form of red tides or algal blooms occur with weak seasonality in the region and more frequently with a strong seasonality along the north Pacific coast (Kudela et al. 2008, Trainer et al. 2009, Band-Schmidt et al. 2010). Among the 12 taxonomic divisions and three kingdoms (Cavalier-Smith 1993, Falkowski et al. 1998, 2004) that make up the phytoplankton, the diatoms are one of the most diverse and abundant groups, followed by dinoflagellates, silicoflagellates, and nanoflagellates (Tomas 1997, Falkowski et al. 1998, Mann 1999, Chepurnov et al. 2005, Garcés et al. 2008).

Of the 5000 species comprising marine phytoplankton, only 80 have the capacity to produce toxins that are harmful to human health, directly through shellfish consumption or indirectly through the affect on aquaculture and tourist activities that result in severe economic losses (Hallegraeff 2003). For example, cosmopolitan marine species of the genus Pseudo-nitzschia (H Peragallo, 1899) may bloom in coastal and oceanic regions and under certain conditions produce domoic acid, a neurotoxin responsible for amnesic shellfish poisoning (Bates 1998, Bates et al. 1998, 1989,
Mos 2001). Recently, a large number of bloom events have been reported along Mexican coasts (Sierra-Beltran et al. 1997, Ochoa 2003, Gómez-Aguirre et al. 2004, CortésAltamirano \& Licea-Duran 2004, García-Mendoza et al. 2009). However, studies describing algal blooms in internal coastal bodies influenced by adjacent marine waters are lacking. Thus, the aims of this study were to characterize the phytoplankton community present in Cuyutlan Lagoon (Colima, Mexico) during the algal bloom of December 2009 and to identify the dominant Pseudo-nitzschia species responsible for the bloom.

\section{Materials ANd Methods}

Cuyutlan Lagoon is located on the Mexican Pacific coast, at $18^{\circ} 53^{\prime} \mathrm{N}-19^{\circ} 03^{\prime} \mathrm{N}$ and $104^{\circ} 00^{\prime} \mathrm{W}-104^{\circ} 20^{\prime} \mathrm{W}$ (Fig. 1), and is a shallow coastal lagoon (depth average of $80 \mathrm{~cm}$ ). It exchanges water with the sea at three points: the Tunnel, near the port of Manzanillo; through water intake from the Ventanas Channel which is used for the cooling of the condensers at the electric power plant; and across the Tepalcates Channel; these engineering works divide it into 4 basins. The lagoon circulation is determined by the tidal interaction through its marine communications and by the wind drag over its surface; close to the sites of water exchange the maximum depth reaches $5 \mathrm{~m}$ (SAGARPA 2004¹ , Patiño-Barragán et al. 2008).

For the present study, samples were made at eight stations located in areas influenced by tidal exchange (parts of the basins II and III) and were carried out on $28^{\text {th }}$ December 2009 between 9:30 and 14:00 h. Basin II is bounded by the railway embankment and the Tepalcates Bridge, while basin III is located between this bridge and a gate which regulates water flow. The average depth of this part of the lagoon is between 30 and $190 \mathrm{~cm}$.

Temperature and salinity were measured in situ with an YSI probe (model 85), and $\mathrm{pH}$ with an $\mathrm{HACH}$ model sensION 2 potentiometer. Surface-seawater was collected for nutrient analysis using a Skalar San Plus autoanalyzer, as described in Grasshoff et al. (1983). Samples for chlorophyll $a$ extraction were kept in the dark at $4^{\circ} \mathrm{C}$ and then filtered as needed through glass filters $(0.7 \mu \mathrm{m}$ pore size). Chlorophyll $a$ was acetone-extracted and then quantified in a spectrophotometer (Perkin-Elmer model Lamba 35) according to Strickland \& Parsons (1972).

${ }^{1}$ SAGARPA. 2004. Ecosistemas lagunares costeros. Diario oficial, Quinta sección, 129 pp. Secretaria de Agricultura, Ganadería, Desarrollo Rural, Pesca y Acuacultura, México. 
Figure 1. Study area, showing the location of sampling stations (S1-S8) / Área de estudio, indicando las estaciones de muestreo (S1-S8)

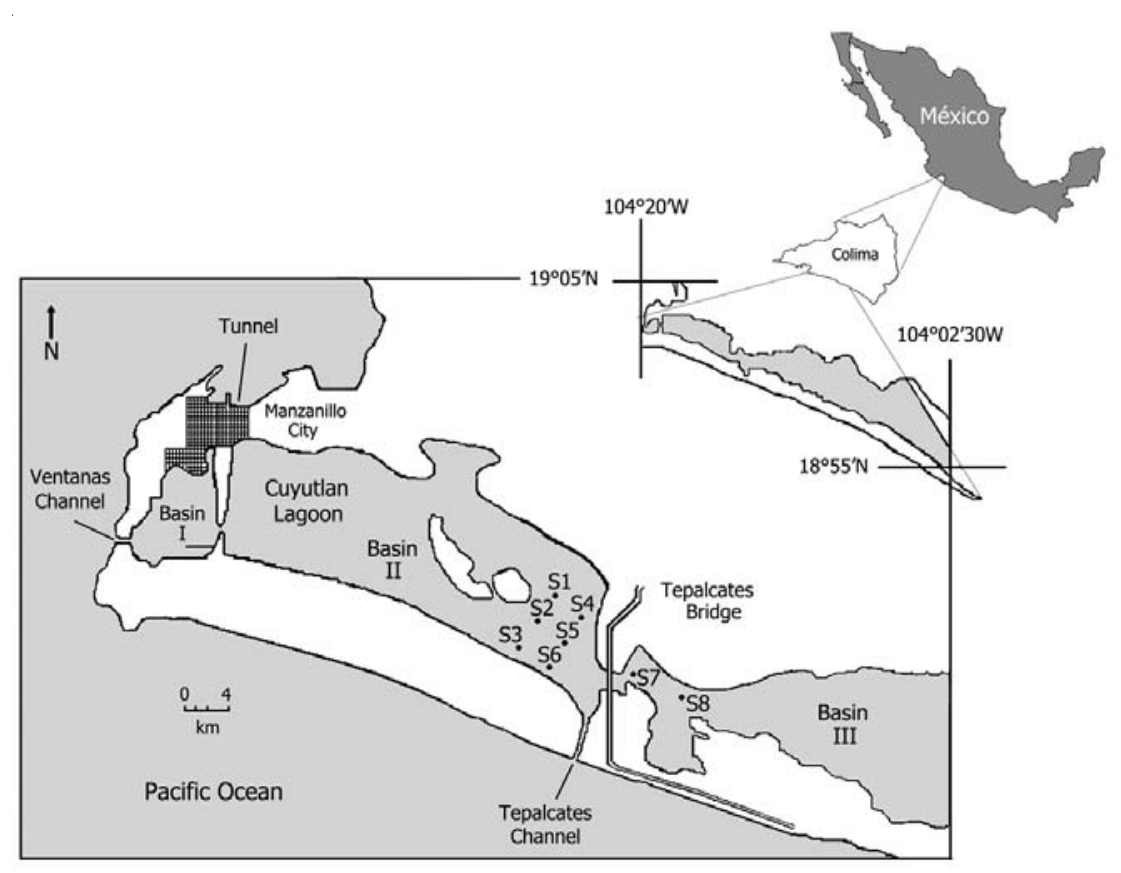

For taxonomic identification $100 \mathrm{~mL}$ of superficial water was fixed with Lugol's solution. Phytoplankton subsamples were examined using sedimentation chambers and an area with a representative number of cells enumerated $(20 \mathrm{~mL}$ settled and more than 300 cells enumerated) under an inverted bright-field light microscope at 200-400x magnification (Motic AE31) (Throndsen 1995). Identification was generally to the genus level and abundance reported as cells $\mathrm{L}^{-1}$ with a limit of detection by this method of 20 cells $L^{-1}$ (Utermöhl 1931). When light microscopy observations revealed a Pseudo-nitzschia abundance $>2 \times$ $10^{4}$ cells $\mathrm{L}^{-1}$, the cells were further examined by scanning electron microscopy. Organic material was removed from the samples with sulfuric acid and potassium permanganate, followed by the addition of oxalic acid, as described in Lundholm et al. (2002). The remaining material was mounted on a polycarbonate filter, attached on stubs with colloidal silver, sputter-coated with gold, and then observed at 20-30 kV in a Jeol JSM- $390 \mathrm{LV}$ scanning electron microscope (SEM). In each sample, organisms identified as Pseudo-nitzschia were examined for morphometric characteristics (width and length of the valve, density of striae, fibulae and poroids) under SEM in a different and appropriate area of the filter, from one transect to a whole filter depending on the cell abundance (minimum cell number measured $=30$ ). The percentages of each species found in SEM were applied to the cell counts.

\section{Results}

\section{Physicochemical parameters}

The surface water temperature varied from 24.3 to $26.9^{\circ} \mathrm{C}$, with the minimum at station $\mathrm{S} 1$ and the maximum at station S8. Dissolved oxygen values were between 5.6 and $8.5 \mathrm{mg}$ $\mathrm{L}^{-1}$, with the minimum at station $\mathrm{S} 1$ and the maximum at station S8. Salinity ranged from 34.4 to 34.8 psu, with the minimum at station S3 and the maximum at station S1. The $\mathrm{pH}$ values were homogeneous, ranging from 7.9 to 8.1 (Table 1).

Nutrients and chlorophyll $a$ : Dissolved inorganic nutrients, defined as nitrates and nitrites $\left(\mathrm{NO}_{2}{ }^{-}+\mathrm{NO}_{3}{ }^{-}\right)$, were present in concentrations ranging from 0.68 to $5.17 \mu \mathrm{M}$, with the lowest value measured at station (S3) at basin II and the highest at basin III of the lagoon (S7). Ammonium $\left(\mathrm{NH}_{4}^{+}\right)$concentrations ranged from 1.63 to $2.4 \mu \mathrm{M}$. Phosphates $\left(\mathrm{PO}_{4}^{3-}\right)$ concentrations were between 0.01 (S5, S6, and S8) and $3.63 \mu \mathrm{M}$ (S3). Silicates $\left(\mathrm{SiO}_{2}\right)$ ranged from 
Table 1. Abiotic and biotic parameters for the Cuyutlan basins: Temperature (T), Dissolved Oxygen (DO), Salinity (S), $\mathrm{pH}, \mathrm{NO}_{2}+\mathrm{NO}_{3}, \mathrm{NH}_{4}^{+}, \mathrm{PO}_{4}^{-3}, \mathrm{SiO}_{2}$, Chlorophyll a concentration / Parámetros abióticos y bióticos de la cuenca de Cuyutlán: Temperatura (T), Oxígeno Disuelto (DO), Salinidad (S), $\mathrm{pH}, \mathrm{NO}_{2}^{-}+\mathrm{NO}_{3}, \mathrm{NH}_{4}^{+}, \mathrm{PO}_{4}^{-3}, \mathrm{SiO}_{2}$, Concentración de clorofila a

\begin{tabular}{lccccccccc}
\hline Station & $\mathrm{T}\left({ }^{\circ} \mathrm{C}\right)$ & $\mathrm{DO}\left(\mathrm{mg} \mathrm{L}^{-1}\right)$ & $\mathrm{S}(\mathrm{psu})$ & $\mathrm{pH}$ & $\begin{array}{c}\mathrm{NO}_{2}{ }^{-}+\mathrm{NO}_{3}{ }^{-} \\
(\mu \mathrm{M})\end{array}$ & $\begin{array}{c}\mathrm{NH}_{4}{ }^{+} \\
(\mu \mathrm{M})\end{array}$ & $\begin{array}{c}\mathrm{PO}_{4}{ }^{-3} \\
(\mu \mathrm{M})\end{array}$ & $\begin{array}{c}\mathrm{SiO}_{2} \\
(\mu \mathrm{M})\end{array}$ & $\begin{array}{c}\text { Chlorophyll } \\
\left(\mathrm{mg} \mathrm{Chl} a \mathrm{~m}^{-3}\right)\end{array}$ \\
\hline $\mathrm{S} 1$ & 24.3 & 6.3 & 34.8 & 8.1 & 2.43 & 1.89 & 0.01 & 7.11 & 1.06 \\
$\mathrm{~S} 2$ & 24.7 & 6.4 & 34.5 & 7.9 & 3.34 & 1.96 & 0.24 & 6.29 & 0.71 \\
$\mathrm{~S} 3$ & 24.5 & 6.8 & 34.3 & 7.9 & 0.68 & 2.40 & 3.63 & 5.38 & 0.62 \\
$\mathrm{~S} 4$ & 25.9 & 7.2 & 34.5 & 8.0 & 0.77 & 1.86 & 0.19 & 5.87 & 0.79 \\
S5 & 25.9 & 7.3 & 34.4 & 8.0 & 4.33 & 2.39 & 0.01 & 8.49 & 0.94 \\
$\mathrm{~S} 6$ & 26.4 & 6.7 & 34.5 & 8.0 & 2.8 & 1.91 & 0.01 & 8.46 & 1.00 \\
S7 & 26.8 & 7.9 & 34.5 & 8.0 & 5.17 & 1.63 & 0.17 & 7.38 & 1.30 \\
$\mathrm{~S} 8$ & 26.9 & 8.5 & 34.5 & 8.1 & 3.56 & 1.74 & 0.01 & 8.21 & 1.74 \\
\hline
\end{tabular}

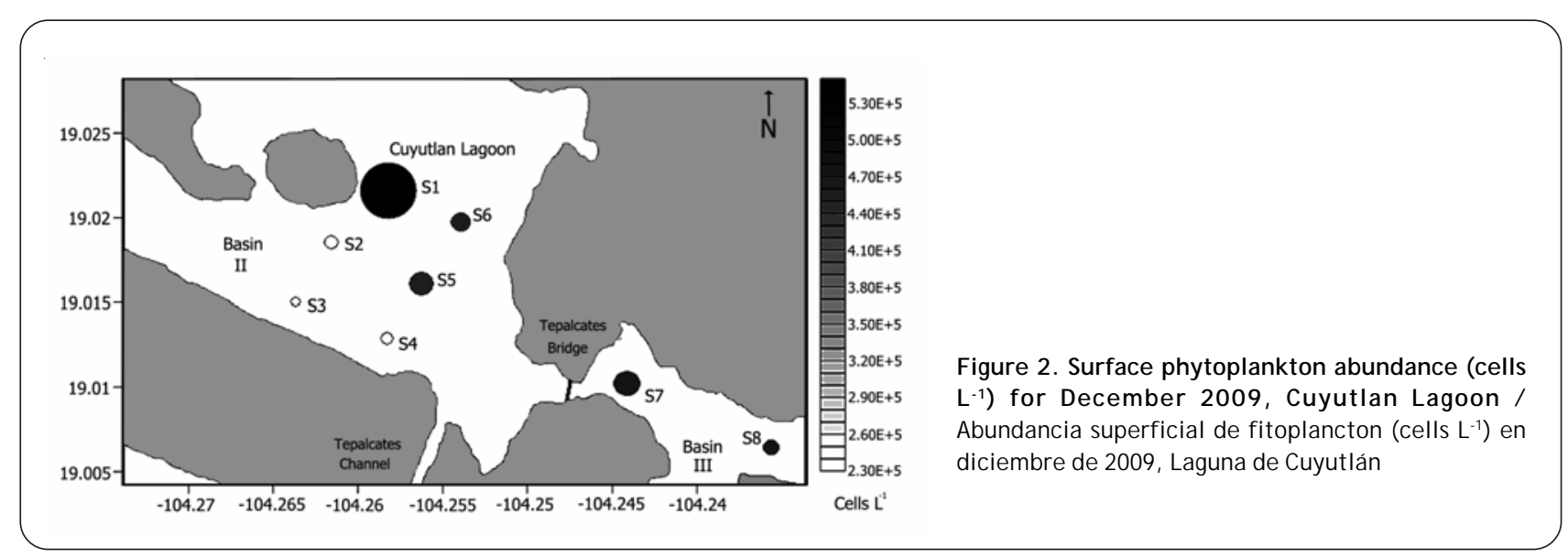

5.38 (S3) to $8.21 \mu \mathrm{M}$ (S8) (Table 1). Chlorophyll $a$ concentrations varied from 0.62 to $1.74 \mathrm{mg} \mathrm{Chl} a \mathrm{~m}^{-3}$, registered at station S3 and S8, respectively (Table 1).

\section{Phytoplankton abundance}

The lowest abundances $\left(2.44 \times 10^{5}\right.$ cells $\left.\mathrm{L}^{-1}\right)$ were detected at station S2 (Figs. 2, 3) while at stations S1 and S5-S8 the values were higher, ranging from $5.4 \times 10^{5}$ cell $\mathrm{L}^{-1}$ at station S1 to $4.4 \times 10^{5}$ cells $\mathrm{L}^{-1}$ at station S8 (Figs. 2, 3). At all stations, the taxonomic composition of large phytoplankton groups was dominated by diatoms, with the lowest relative abundance measured at station S8 (71.4\%). The highest

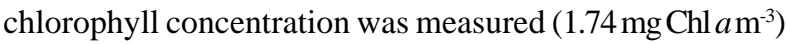
and the highest was found at station S4 (90.3\%) (Fig. 4, Table 1). The second most abundant group were the nanoflagellates, accounting for $24.8 \%$ of the relative abundance at station S8 but only $9.7 \%$ at station S4 (Fig. 4). Dinoflagellates were poorly represented, accounting only

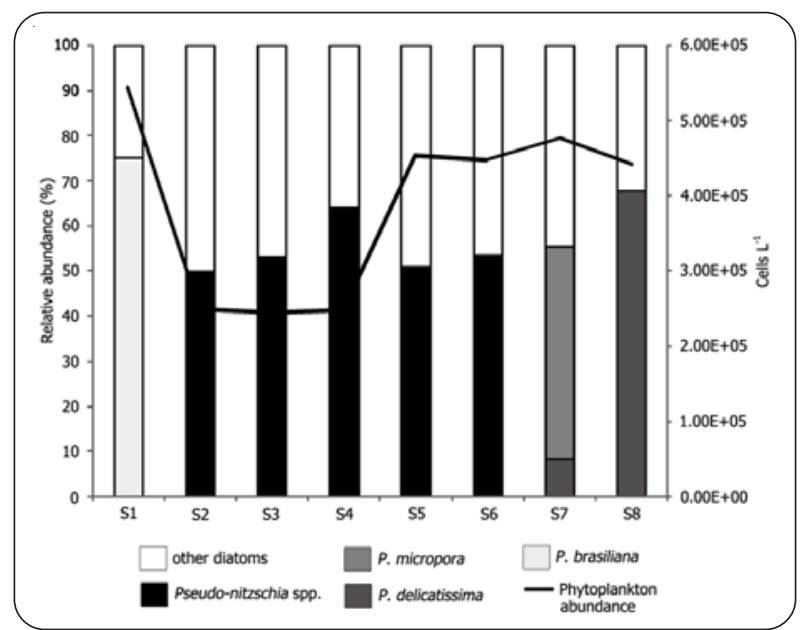

Figure 3. Relative abundances (\%) of the most abundant Pseudonitzschia species in relation to all diatoms (vertical bars). Total phytoplankton abundance (cells $\mathrm{L}^{-1}$ ) is noted by the solid black line / Abundancias relativas (\%) de las Pseudo-nitzschia más abundantes en relación a las diatomeas totales (barras verticales). La línea negra sólida indica la abundancia total de fitoplancton (cells $\mathrm{L}^{-1}$ ) 
$2.1 \%$ of the relative abundance at station S5 and completely absent at stations S1, S4 and E7 (Fig. 4).

Among the diatom groups, the most abundant genus was Pseudo-nitzschia; its relative abundance was high at all stations, with a maximum of $74.3 \%$ at station S1 and a minimum of $50 \%$ at station S2 (Fig. 3). Three species were found and characterized as follows:

Pseudo-nitzschia brasiliana (Lundholm, Hasle and Fryxell, 2002). This diatom has rectangular shape lacks a central nodule. The species morphometric data coincided with the original description and literature data. (Table 2; Fig. 5A, D). This was the predominant species, with abundance at station S1 of $3.4 \times 10^{5}$ cells L $^{-1}$ (Fig. 3).

Pseudo-nitzschia delicatissima (Cleve) Heiden, 1928. This diatom has lanceolate form and a central nodule. Their morphometric values were similar to those found in the literature (Table 2, Fig. 5C, F). It occurred at station S7 but was not the dominant species, representing only $8.3 \%$ of the Pseudo-nitzschia identified. However, at station S8 it was the only species identified, with an abundance of $2.1 \times$ $10^{5}$ cells $\mathrm{L}^{-1}$ (Fig. 3).
Pseudo-nitzschia micropora (Priisholm, Moestrup \& Lundholm 2002). This lanceolate-shaped diatom lacks a central nodule (Table 2, Fig. 5B, E). It was found only at station S7, with an abundance of $1.8 \times 10^{5}$ cells L $^{-1}$, accounting for $85 \%$ of Pseudo-nitzschia at this location (Fig. 3).

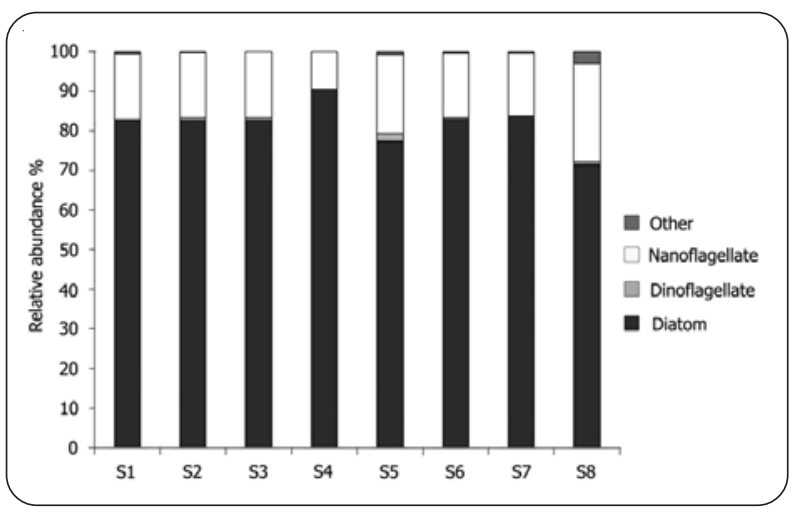

Figure 4. Relative abundances (\%) of the principal taxonomic components of phytoplankton / Abundancias relativas de los principales componentes taxonómicos del fitoplancton
Figure 5. Scanning electron microscopy images of Pseudo-nitzschia collected from Cuyutlan Lagoon. A, D) P. brasiliana, B, E) P. micropora, C, F) P. delicatissima. (Scale bars A, B and C: $5 \mathrm{~mm}$, D and F: $1 \mathrm{~mm}, \mathrm{E}: 0.5 \mathrm{~mm}$ ) / Imágenes de microscopio electrónico de Pseudo-nitzschia colectadas en la Laguna de Cuyutlán. A, D) P. brasiliana, B, E) P. micropora, C, F) P. delicatissima. (Barra de escala A, B y C: $5 \mathrm{~mm}$, D y F: $1 \mathrm{~mm}, \mathrm{E}: 0,5 \mathrm{~mm}$ )

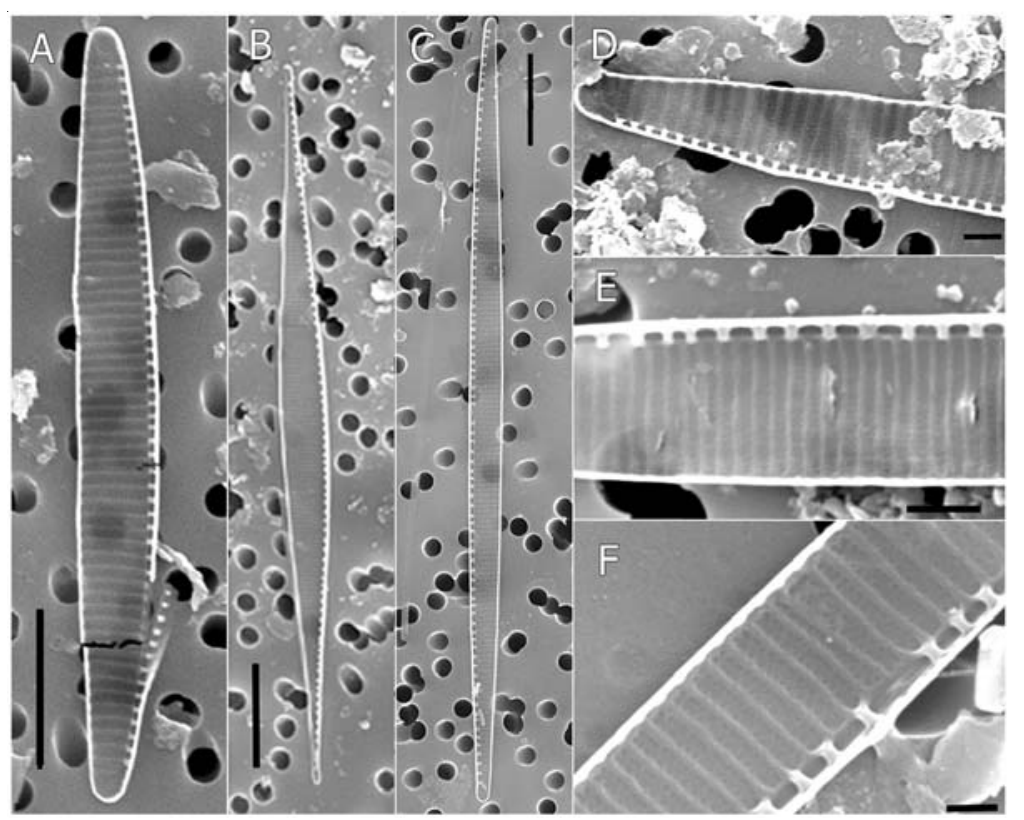


Table 2. Representative morphological characteristics of the Pseudo-nitzschia species as observed in field samples from Cuyutlan Lagoon and the comparison with data from examined literature. All measurements were done using the scanning electron microscopy method / Características morfológicas representativas de las especies de Pseudo-nitzschia observadas en muestras naturales de la Laguna de Cuyutlán y comparadas con datos de literatura. Todas las mediciones se llevaron a cabo a través de microscopia electrónica de barrido

\begin{tabular}{|c|c|c|c|c|c|c|c|c|c|}
\hline Species & $\begin{array}{l}\text { Shape of } \\
\text { valve }\end{array}$ & Fibulae* & Striae* & $\begin{array}{l}\text { Rows of } \\
\text { poroids }\end{array}$ & Poroids** & $\begin{array}{l}\text { Central } \\
\text { nodule }\end{array}$ & $\begin{array}{l}\text { Apical } \\
\text { axis }\end{array}$ & $\begin{array}{l}\text { Trans- } \\
\text { apical axis }\end{array}$ & Data from examined literature \\
\hline \multirow[t]{3}{*}{ P. brasiliana } & rectangular & $23-24$ & $19-25$ & 2 & $7-9$ & - & $24-31.7$ & $2.7-3$ & Present study \\
\hline & & $20-26$ & $20-26$ & & $7-10$ & & $12-65$ & $1.8-3$ & $\begin{array}{l}\text { Hasle (1995), Lundholm et al. } \\
\text { (2003) }\end{array}$ \\
\hline & & $22-27$ & $23-28$ & & $7-10$ & & $34.1-39.4$ & $2.3-3.3$ & Quijano-Scheggia et al. (2008) \\
\hline \multirow[t]{4}{*}{ P. delicatissima } & lanceolate & $18-24$ & $31-35$ & 2 & $10-12$ & + & $34.8-38.2$ & $1.8-2.1$ & Present study \\
\hline & & $19-26$ & $35-40$ & & $8-12$ & & $19-76$ & $1.5-2$ & $\begin{array}{l}\text { Hasle (1995), Lundholm et al. } \\
\text { (2003) }\end{array}$ \\
\hline & & $20-30$ & $33-42$ & & $9-12.5$ & & $39-71$ & $1.3-1.7$ & Kaczmarska et al. (2005) \\
\hline & & $20-28$ & $36-42$ & & $9-11$ & & $32.3-78$ & $1.01-2.4$ & Quijano-Scheggia et al. (2008) \\
\hline \multirow[t]{3}{*}{ P. micropora } & lanceolate & $21-24$ & $27-36$ & 2 & $8-11$ & - & $33.1-38.2$ & $1.9-2.5$ & Present study \\
\hline & & $22-27$ & $43-49$ & & $11-17$ & & $27.5-39.2$ & $1.8-2.6$ & Quijano-Scheggia et al. $(2010)^{2}$ \\
\hline & & $21-29$ & $41-46$ & & $9-12$ & & $31-57$ & $1.3-2$ & Priisholm et al. (2002) \\
\hline
\end{tabular}

$*$ in $10 \mu \mathrm{m} ; * *$ in $1 \mu \mathrm{m}$

\section{Discussion}

Cuyutlan Lagoon has high economic value for the State of Colima, which is based on its fishing, salt extraction, and eco-tourism activities. However, the lagoon has not been systematically monitored with the aim of detecting harmful algal blooms. While algal blooms have been observed in the area, their toxicity was not assessed. Quijano-Scheggia et al. (2006) described the effect on phytoplankton communities, and especially diatoms, over two annual cycles (1989-1990 and 1991-1993), during periods when the Tepalcates Channel was open/closed. They reported that salinity and temperature are the controlling physical factors in the observed alterations of species composition. Specifically, when the Channel was open the diversity and abundance of planktonic diatoms increased.

Nutrient concentrations at the study site were limited with respect to Phosphate according to the criteria of Justic et al. (1995), however, despite this it was in the range measured in other tropical coastal lagoons of the Mexican Pacific (Contreras-Espinosa 1985, ContrerasEspinosa et al. 1997). In Cuyutlan Lagoon, like Falcao \& Vale (2003) and Carr et al. (2010) report, the nutrient levels are related to the dynamic interaction of low depth and the influence of wind/tide strength that causes resuspension of organic and inorganic material from sediments, as observed in basin II. The higher nutrient concentrations of basin III can be explained by the increased water residence time that enhances the remineralization of organic matter.This relates to the fact that toward internal stations (S1 or S8) salinity and temperature values are also higher, which is an indicator that in this part of the lagoon water exchange is lower and allows evaporation and higher salinities, as reported in other coastal lagoons (Mudge et al. 2008, Malhadas et al. 2010). The spatial distribution in temperature can be supported with a correlation coefficient of 0.96 against the distance from each station to the Tepalcates Channel.

Several Pseudo-nitzschia species were identified from the Cuyutlan Lagoon samples where the most abundant was $P$. brasiliana. This species is non-toxic and opportunistic, proliferating when environmental conditions are optimal (e.g., temperature $>24^{\circ} \mathrm{C}$, as was the case at station S1 during the study period), but decreasing to levels barely within detection limits when conditions become unfavorable (Villac et al. 2005, QuijanoScheggia et al. 2010). The second most abundant Pseudo-

${ }^{2}$ Quij ano-Scheggia S, M Rivera-Vilarelle, E Garcés, A Olivos-Ortiz, J H Gaviño-Rodríguez, K Zepeda-Borja, MA Galicia-Pérez \& M Patiño-Barragán. 2010. Seasonal diversity of Pseudo-nitzschia spp. in the central zone of the Mexican Tropical Pacific, Manzanillo, Colima, 14th International Conference on Harmful Algae, Hersonisson, Crete, Greece. 
nitzschia species was $P$. delicatissima, a species hard to identify that is potentially toxic (Moestrup et al. 2011). It was found at stations S7 and S8, i.e., far from Tepalcates Channel (the communication between the sea and the lagoon), where hydrodynamic conditions promote higher availability of $\mathrm{NO}_{2}^{-}+\mathrm{NO}_{3}^{-}$and a low concentration of $\mathrm{PO}_{4}^{-3}$ possibly due to the assimilation of this nutrient from phytoplankton as proposed by Boyle et al. (2004). This fact is related to the maximum values of chlorophyll $a$ (1.3 and $1.74 \mathrm{mg}$ Chl $a \mathrm{~m}^{-3}$ respectively Table 1$)$. The third most abundant species was P. micropora, which is typically found in temperate to warm waters (around $28^{\circ} \mathrm{C}$ ) similar to the environment of the Cuyutlan Lagoon. This species has thus far been described only in Vietnam and Thailand (Priisholm et al. 2002) but was found in abundance inside basin III (S7), where the low water exchange results in longer residence times and higher water temperatures. The Port of Manzanillo is the most important of the Mexican Pacific, it handles $68 \%$ of the load up through the Mexican Pacific and its zone of influence extends to 74 international destinations, with marine traffic including large ships coming directly from Asian countries such as Indonesia, Hong Kong, China, South Korea, Taiwan, Malaysia, Singapore and the Philippines (ApiMan 2009) ${ }^{3}$. We assume that the detected range of environmental parameters and the proximity of the Port of Manzanillo are the factors which led to the presence of these species within the lagoon, due to the exchange of ballast water from these ships as reported by Hallegraeff (2003).

Further studies are recommended to identify and detect the emergence of new species capable of producing harmful algal blooms in Cuyutlan Lagoon and adjacent coastal areas. And finally, for Pseudo-nitzschia brasiliana and P. micropora, this is the first report for these species in the Mexican Pacific.

\section{ACKNOWLEDGMenTs}

We thank K. Zepeda Borja for her work in processing phytoplankton samples and Dr. J. Reyes Gomez and D. Pozas Zepeda for microphotography and assistance with SEM. We also thank the University of Colima for financially supporting this work.

\section{LITERATURE CITED}

Band-Schmidt CJ, J Bustillos-Guzmán, D López-Córtes, I Gárate-Lizárraga, EJ Núnez-Vázquez \& FE Hernández-Sandoval. 2010. Ecological and physiological studies of Gymnodinium catenatum in the Mexican Pacific: A Review Mar Drugs 8: 1935-1961.

Bates SS. 1998. Ecophysiology and metabolism of ASP toxin production. In: Anderson D, A Cembella \& GM Hallegraeff (eds). Physiological ecology of harmful algal blooms, pp. 405-426. Springer-Verlag, Berlin.

Bates SS, DL Garrison \& R Horner. 1998. Bloom dynamics and physiology of domoic-acid-producing Pseudo-nitzschia species. In: Anderson D, A Cembella \& GM Hallegraeff (eds). Physiological ecology of harmful algal blooms, pp. 267-292. Springer Verlag, Berlin.

Bates SS, CJ Bird, ASW de Freitas, R Foxall, M Gilgan, LA Hanic, GR Johnson, AW McCulloch, P Odense, $R$ Pocklington, MA Quilliam, PG Sim, JC Smith, DV Subba-Rao, ECD Tood, JA Walter \& JLC Wright. 1989. Pennate diatom Nitzschia pungens as the primary source of domoic acid, a toxin in shellfish from eastern prince Edward island, Canada. Canadian Journal of Fisheries and Aquatic Science 46: 1203-1215.

Boyle KA, K Kamer \& P Fong. 2004. Spatial and temporal patterns in sediment and water column nutrients in a eutrophic southern California estuary. Estuaries 27(3): 378388.

Carr J, P D’Odorico, K McGlathery \& P Wiberg. 2010. Stability and bistability of seagrass ecosystems in shallow coastal lagoons: Role of feedbacks with sediment resuspension and light attenuation. Journal of Geophysical Research-Biogeosciences 115: 1-14.

Cavalier-Smith T. 1993. Kingdom Protozoa and its 18 Phyla. Microbiological Reviews 57: 953-994.

Colbert D \& J McManus. 2003. Nutrient biogeochemistry in an upwelling-influenced estuary of the Pacific Northwest (Tillamook Bay, Oregon, USA). Estuaries and Coasts 26: 1205-1219.

Contreras-Espinosa F. 1985. Las lagunas costeras mexicanas, 253 pp. Secretaría de Pesca, México.

Contreras-Espinosa F, O Castaneda \& L Torres. 1997. Hidrología, nutrientes y productividad primaria en las lagunas costeras del Estado de Oaxaca, México. Hidrobiológica 7: 9-17.

Cortés-Altamirano R \& S Licea-Duran. 2004. Decoloración en proliferaciones de microalgas como parámetro bioindicador en la Bahía de Mazatlán, México. Revista de Biología Tropical 52(Suppl.1): 27-34.

${ }^{3}$ ApiMan. 2009. Administración Portuaria Integral de Manzanillo, <http://www.puertomanzanillo.com.mx/php/esp/ index. php?eCodSeccion $=>$. 
Chepurnov VA, DG Mann, K Sabbe, K Vannerum, G Casteleyn, E Verleyen, L Peperzak \& W Vyverman. 2005. Sexual reproduction, mating system, chloroplast dynamics and abrupt cell size reduction in Pseudo-nitzschia pungens from the North Sea (Bacillariophyta). European Journal of Phycology 40: 379-395.

Falcao M \& C Vale. 2003. Nutrient dynamics in a coastal lagoon (Ria Formosa, Portugal): The importance of lagoonsea water exchanges on the biological productivity. Ciencias Marinas 29: 425-433.

Falkowski PG, RT Barber \& V Smetacek. 1998. Biogeochemical controls and feedbacks on ocean primary production. Science 281: 200-206.

Falkowski, PG, M Katz, AH Knoll, A Quigg, JA Raven, O Schoeld \& FJR Taylor. 2004. The evolution of modern eukaryotic phytoplankton. Science 305: 354-360.

Garcés E, S Quijano-Scheggia, R Figueroa \& J Camp. 2008. Progresos en el conocimiento de los ciclos de vida de dinoflagelados y diatomeas productoras de Proliferaciones Algales Nocivas. Iridia 5: 64-73.

García-Mendoza E, D Rivas, A Olivos-Ortiz, A AlmazánBecerril, C Castañeda-Vega \& JL Peña-Manjarrez. 2009. A toxic Pseudo-nitzschia bloom in Todos Santos Bay, northwestern Baja California, México. Harmful Algae 8: 493-503.

Gómez-Aguirre S, S Licea \& S Gómez. 2004. Proliferaciones de Pseudo-nitzschia spp. (Bacillariophyceae) y otras especies del microplancton en la Bahía de Mazatlán, México. Revista de Biología Tropical 52 (Suppl. 1): 69-76.

Grasshoff K, M Ehrrardt \& K Kremling. 1983. Methods of sea water analysis, $345 \mathrm{pp}$. Chemie, Weinheim.

Hallegraeff GM. 2003. Harmful algal blooms: a global overview. In: Hallegraeff GM, DM Anderson \& AD Cembella (eds). Manual on harmful marine microalgae. Monographs on oceanographic methodology, pp. 25-49. UNESCO, Paris.

Hasle GR. 1995. Pseudo-nitzschia pungens and P. multiseries (Bacillariophyceae): nomenclatural history, morphology, and distribution. Journal of Phycology 31: 428-435.

Justic D, NN Rabalais, RE Turner \& Q Dortch. 1995. Changes in nutrient structure of river-dominated coastal waters: stoichiometric nutrient balance and its consequences. Estuarine Coastal and Shelf Science 40: 339356.

Kaczmarska I, MM LeGresley, JL Martin \& J Ehramn. 2005. Diversity of the diatom genus Pseudo-nitzschia Peragallo in the Quoddy Region of the Bay of Fundy, Canada. Harmful Algae 4: 1-19.

Kress N, S Leon-Coto, CL Brenes \& S Brener. 2002. Horizontal transport and seasonal distribution of nutrients, dissolved oxygen and chlorophyll-a in the Gulf of Nicoya, Costa Rica: a tropical estuary. Continental Shelf Research 22: 51-66.
Kudela RM, JQ Lane \& WP Cochlan. 2008. The potential role of anthropogenically derived nitrogen in the growth of harmful algae in California, USA. Harmful Algae 8: 103-110.

Lundholm N, N Daugbjerg \& Ø Moestrup. 2002. Phylogeny of the Bacillariaceae with emphasis on the genus Pseudonitzschia (Bacillariophyceae) based on partial LSU rDNA. European Journal of Phycology 37: 115-134.

Lundholm N, Ø Moestrup, GR Hasle \& K Hoef-Emden. 2003. A study of the Pseudo-nitzschia pseudodelicatissima/ cuspidata complex (Bacillariophyceae): what is $P$. pseudodelicatissima? Journal of Phycology 39: 797-813.

Malhadas M, R Neves, $P$ Leitão \& A Silva. 2010. Influence of tide and waves on water renewal in Óbidos Lagoon, Portugal. Ocean Dynamics 60: 41-55.

Mann DG. 1999. The species concept in diatoms. Phycologia 38: 437-495.

Moestrup Ø, R Akselman, G Cronberg, M Elbraechter, S Fraga, Y Halim, G Hansen, M Hoppenrath, J Larsen, N Lundholm, L Nguyen, A Zingone. 2011. IOC-UNESCO Taxonomic Reference List of Harmful Micro Algae. [on line] http: // www. marinespecies . org / hab /aphia. php?p = taxdetails \& id = 109612 on 2011-06-07

Mos L. 2001. Domoic acid: a fascinating marine toxin. Environmental Toxicology and Pharmacology 9: 79-85.

Mudge SM, JD Icely \& A Newton. 2008. Residence times in a hypersaline lagoon: Using salinity as a tracer. Estuarine Coastal and Shelf Science 77: 278-284.

Patiño-Barragán M, MA Galicia-Pérez, JH GaviñoRodríguez, AO Meyer-Willerer, A Olivos-Ortiz \& JC Chávez-Comparan. 2008. Diagnóstico ambiental de la Laguna de Cuyutlán, Colima. En: Quintanilla-Montoya AL \& A Iracheta-Conecorta (eds). Ciudad, puerto y turismo: estrategias para una integración sustentable, pp. 45-56. El Colegio Mexiquense, México.

Priisholm K, Ø Moestrup \& N Lundholm. 2002. Taxonomic notes on the marine diatom genus Pseudo-nitzschia in the Andaman Sea near the island of Phuket, Thailand, with a description of Pseudo-nitzschia micropora sp. nov. Diatom Research 17: 153-175.

Quijano-Scheggia S, MC Jiménez-Quiroz, A OlivosOrtiz, MA Galicia-Pérez, JH Gaviño-Rodríguez \& AO Meyer-Willerer. 2006. Cambios en la comunidad de diatomeas de la laguna de Cuyutlán (Colima, México), resultantes de la apertura de un canal de comunicación con el océano Pacífico. En: Jiménez-Quiroz MC \& E EspinoBarr (eds). Los recursos pesqueros y acuícolas de Jalisco, Colima y Michoacán, pp. 335-356. SAGARPA, Instituto Nacional de la Pesca, Jalisco.

Quijano-Scheggia S, E Garces, N Sampedro, K van Lenning, E Flo, K Andree \& JM Fortuno. 2008. Identification and characterisation of the dominant Pseudonitzschia species (Bacillariophyceae) along the NE Spanish coast (Catalonia, NW Mediterranean). Scientia Marina 72: 343-359. 
Quijano-Scheggia S, E Garcés, K Andree, P de la Iglesia, J Diogène, JM Fortuño \& J Camp. 2010. Pseudo-nitzschia species in the Catalan Coast: characterization and contribution to the current knowledge of genus distribution in the Mediterranean Sea. Scientia Marina 74: 395-410.

Sierra-Beltran A, M Palafox-Uribe, J Grajales-Montiel, A Cruz-Villacorta \& JL Ochoa. 1997. Sea bird mortality at Cabo San Lucas, México: evidence that toxic diatom blooms are sprading. Toxicon 35: 447-453.

Strickland JD \& TR Parsons. 1972. A practical handbook of sea water analysis. Bulletin, Fisheries Research Board of Canada 167: 1-310.

Throndsen J. 1995. Estimating cell numbers. In: Hallegraeff GM, DM Anderson \& AD Cembella (eds). Manual on harmful marine microalgae, pp. 63-80. IOC Manual and Guides UNESCO, Paris.
Tomas CR. 1997. Identifying marine phytoplankton, 858 pp. Academic Press, San Diego.

Trainer VL, BM Hickey, EJ Lessard, WP Cochlan, CG Trick, ML Wells, A MacFadyen \& SK Moore. 2009. Variability of Pseudo-nitzschia and domoic acid in the Juan de Fuca eddy region and its adjacent shelves. Limnology and Oceanography 54: 289-308.

Utermöhl H. 1931. Neue Wege in der quantitativen Erfassung des Planktons.Verhandlungen des Internationalen Verein Limnologie 5: 567-595.

Villac MC, S Melo, M Menezes \& D Rivera. 2005. Pseudonitzschia brasiliana (Bacillariophyceae), an opportunistic diatom on the coast of the state of Rio de Janeiro, Brazil. Atlântica, Río Grande 27: 139-145.

Received 01 February 2011 and accepted 19 May 2011 